\title{
I A NATURALEZA HUMANA ANTE EL DESARROLLO CIENTÍFICO Y TECNOLÓGICO
}

\section{Human nature before scientific And technological developments}

Francisco Luis Giraldo $G^{*}$

\section{Resumen}

La reflexión que presento a continuación tiene como referentes teóricos los planteamientos presentados por José Luis Molinuevo en su texto Humanismo y Nuevas Tecnologías (2004) y José Ortega y Gasset en Meditación de la técnica y otros ensayos sobre ciencia y filosofía (2002). De igual modo, considero algunos plateamientos hechos por Martín Heidegger en Cartas sobre el humanismo (1959) y Ciencia y Técnica (2002). Así, la pregunta tácita de este texto es si el hombre, en esta carrera desaforada por la ciencia y la tecnología, ha perdido su estatus y calidad de sujeto racional, cuestionando si las condiciones y modos de racionalidad del hombre actual son propias de él mismo o, si por el contrario, hoy en día se presenta una pérdida, a modo de desfase, entre lo que tradicionalmente conocemos como «humano» y lo que actualmente es el hombre, o si esos conceptos de «humano» $y$ «humanidad» serán renovados en su totalidad.

Palabras clave: hombre, humanidad, ciencia, tecnología, identidad, especies, cosa, masa.

\footnotetext{
" Profesor- Investigador del INSTITUTO TECNOLÓGICO METROPOLITANO -ITM-. Miembro del grupo de investigación Ciencia, Tecnología y Sociedad (cts) del mismo Instituto. franciscogrialdo@itm.edu.co

Fecha de recepción: 22 de febrero Fecha de aceptación: 25 de marzo
}

\section{Abstract}

The reflection herewith presented has, as theoretical guidelines, the approaches taken by José Luis Molinuevo in his text Humanism and New Technologies, and José Ortega y Gasset's Meditation about technique and other essays on science and philosophy. Similarly, some ideas from Martin Heidegger's Letters on Humanism and Science and Technology were considered. It is thus how the question implied in this text is whether man, in this unbridled career towards science and technology, has lost his status and quality as a rational subject, wondering if his conditions and the modes of rationality as a modern man are proper to him, or, to the contrary, there is a current loss, in a way of a mismatch, between what is traditionally known as a "human" and what really man is today, or whether the concepts of "human" and "humanity" will be completely renovated.

Keywords: man, humanity, science, technology, identity, species, object, mass.

\section{Introducción}

La reflexión que presento a continuación tiene como referentes teóricos los planteamientos presentados por José Luis Molinuevo en su texto Humanismo y Nuevas 
Tecnologías (2004) y José Ortega y Gasset en Meditación de la técnica y otros ensayos sobre ciencia y filosofía (2002). De igual modo, considero algunos plateamientos hechos por Martín Heidegger en Cartas sobre el humanismo (1959) y Ciencia y Técnica (2002). A partir de estos textos, contextualizo la problemática de la pérdida o desleimiento del ser humano ante el desarrollo de la ciencia y la tecnología, a través de preguntas como qué es, quién es el ser humano en la era tecnocientífica y el dualismo natural/artificial -o la hibridación del hombre- como un asunto del sometimiento ante el desarrollo tecnológico.

Esta reflexión no es una apología -por demás románticaa favor de la humanidad: es, más bien, el reconocimiento de cómo, si bien la especie humana ha sido la artífice de grandes y significativos desarrollos en la ciencia y la tecnología, también es cierto que en su carrera hacia el progreso, se ha convertido en el mayor depredador de los recursos del planeta y el que aún estando en ambientes y condiciones naturales, atenta contra las demás especies vivas.

El hombre ha puesto en riesgo la conservación de la vida en la Tierra, y en su ceguera cientificista no ha dimensionado que los recursos naturales son finitos, que tienen un tiempo y un modo para su desarrollo, y que somos nosotros, los seres humanos, los que estamos llamados a prolongar, en la medida de lo posible, el tiempo de permanencia y abastecimiento de aquellos. De igual modo, es nuestra responsabilidad ética y política establecer las condiciones de vida de las demás especies y coexistencia con ellas. Así, la pregunta tácita en el presente texto es si el hombre, en su carrera desaforada por la ciencia y la tecnología, ha perdido su estatus y calidad de sujeto racional, cuestionando si las condiciones y modos de racionalidad del hombre actual son propias de él mismo 0, si por el contrario, hoy en día se presenta una pérdida, a modo de desfase, entre lo que tradicionalmente conocemos como «humano» y lo que actualmente es el hombre, o si esos conceptos de «humano» $\mathrm{y}$ «humanidad» serán renovados en su totalidad.
El propósito aquí no es presentar una revisión exhaustiva de los textos en mención, sino, más bien, utilizarlos como pretexto -en particular el de José Luis Molinuevo- para caracterizar al hombre, su condición humana, y establecer cómo el desarrollo científico y tecnológico, del cual es el artífice, ha conseguido que en la actualidad sea él mismo quien más lo padece, llegando a tal punto que se habla de una pérdida de la condición humana. Por esto, desde comienzos del siglo xx, al hombre se le endosan los adjetivos de «cosa», «hombre-masa».

Parto en este escenario, de los mitos y parábolas presentados por José Luis Molinuevo en su texto Humanismo y nuevas Tecnologías, contextualizados en la condición humana, en el sentido de qué podemos entender por ella. Como segunda parte en el desarrollo temático, pongo en evidencia cuál es la condición del humano, como ser que padece los embates del desarrollo de la ciencia y la tecnología. En este sentido, no solo aumenta los riesgos de desaparecer como especie en este planeta, sino que obliga, en nuestro tiempo, a pensar en otro nominativo para el ser humano de boy.

\section{Mitos y parábolas como antecedentes de la condición humana y su relación con la tecnología}

Molinuevo contextualiza los orígenes del hombre a partir de tres mitos-relatos: la creación, como el pecado de las imágenes; el juego entre Dios/Adán/Eva; y el mito de la caverna, o la condición de prisioneros de las imágenes: hombre/imágenes/conocimiento. Es el narcicismo tecnológico, como aparente supremacía del hombre, como causante de todo el desarrollo científico y tecnológico. Desde los tres relatos referenciados, el autor plantea:

La historia humana es así una tragicomedia: ejercer el poder porque somos imágenes y ser condenados porque lo somos. A la imagen le acompaña desde sus comienzos un pecado original: tener que verse como copia sin saber lo que es realmente un original. La caída arrastra una condena de la imagen: no poder conocerse desde sí misma, sino a través de simulacros del original que ella misma fabrica. El otro gran mito fundacional de la 
tradición occidental, la caverna platónica, representa de entrada y sin más explicaciones al hombre como condenado, prisionero de las imágenes (Molinuevo, 2004: 18).

El ser humano y su evolución dan muestra de su errado trasegar en este mundo. Los desarrollos social, económico, político y científico-tecnológico en el hombre son el escenario del ensayo y el error, que han traído, en momentos contables y significativos, la más candorosa sonrisa, que se hace evidente cuando el hombre ha dicho «acá estoy», «este soy Yo», cuando en el momento de mostrar una conquista, una innovación, se trata. Pero que de igual manera, el hombre, al momento de asumir su responsabilidad y culpabilidad por todas y tan numerosas acciones atroces que ha cometido, «escurre el costal», «pone pies en polvorosa» y, en el mejor de los casos, indemniza al perjudicado -o perjudicados-, pero no piensa, no calcula, preventiva y prospectivamente, las consecuencias, el riesgo de sus acciones.

De los relatos de Molinuevo vemos cómo el hombre pierde la memoria como condición de acción a partir de lo real, pues la imagen es una parte del todo, la imagen es la manifestación intencionada de lo que el hombre quiere ver o de lo que los otros, que manipulan y conocen los medios de comunicación y el manejo de la información, quieren que vea -lo que le es permitido ver-. El mundo de las imágenes, desde la antigüedad y para siempre, será el mundo de la duda, la ambigüedad, la subjetividad, lo relativo, lo fantástico, lo ideal. La triada relatada por Molinuevo nos deja ver cómo es posible esto.

Se aprecia en el relato de la creación: así Dios haya creado a Eva a partir de una costilla de Adán, fue Él quien idealizó a la mujer, no el hombre. De este modo, se aprecia como «El ser humano crea, como Dios, a imagen suya, pero sin intervención de la mujer. Porque dice el Libro Sagrado que el hombre es la imagen de Dios y la mujer la imagen del hombre» (Molinuevo, 2004: 20). Lo creado por el hombre es representación en cualquier formato, de lo real e irreal, de lo vivido, lo no vivido, lo imaginado y concretado, lo por imaginar y por vivir. La creación de la mujer, mediada por Dios, es el primer elemento para mostrar por el hombre como objeto de su capacidad de representación.

En esa acción creadora, la tecnología tiene su lugar, como lo expresa Molinuevo:

En el relato de los orígenes, las tecnologías tienen una doble legitimación: la de dominio, al ser creado el hombre a imagen y semejanza de Dios, y la de supervivencia, al ser expulsado del Paraíso. La primera constituirá el núcleo de los discursos sobre la dignidad humana; y la segunda, el relativo a los de la indignidad y miseria humanas (Molinuevo, 2004: 19).

La condición humana, la de ser un simple bumano, de manera paradójica, la de ser solo una finitud espacio-temporal, irremediablemente existente para las demás especies, no es más que la mínima manifestación de la capacidad creadora de Dios.

En el relato de la creación, se acude al hombre como testigo de lo que será el desarrollo, el progreso: las nuevas circunstacias de su padecimiento en los tiempos modernos. El hombre, desde el mismo momento de la creación, se presenta otro, no solo a partir de la mujer, sino que, también, cuando el hombre es imaginado y se concreta en la imagen de la creación, comienza a debilitarse como ser humano, comienza a morir antes de nacer, de evolucionar. Hoy en día, con el desarrollo de la nuevas tecnologías, el hombre se «perpetúa» en el tiempo, pero pierde realidad. El hombre de hoy, ante las nuevas tecnologías, es acción en un tiempo pasado. Molinuevo lo expresa así:

Las tecnologías son en buena parte de sus manifestaciones ensayos de una creación continuada. Las imágenes del dedo humano en la creación digital enlazan con el divino de la Capilla Sixtina pintado por Miguel Ángel. Son imágenes de una gran fuerza icónica: Dios se prolonga en el hombre y este en las tecnologías. La creación de seres artificiales a su imagen y semejanza ha sido una obsesión desde los autómatas en las fases primeras de la técnica hasta los sofisticados replicantes, ya que en las biotecnologías se pone de manifiesto que la figura humana no es el modelo anatómico más apropiado de la perfección técnica (Molinuevo, 2004: 19). 
El hombre, en su afán natural de conocer, hace ciencia y desarrolla tecnología; devela el fenómeno, se muestra a sí mismo, pero es incapaz por sus propios medios de superar su condición de humano, su finitud y temporalidad material. Ante esto, Molinuevo nos plantea: «El lema de las tecnologías no debe ser únicamente "[...] y seréis como dioses", sino también "[...] y seréis como hombres"» (Molinuevo, 2004: 20). La realidad material ya no le es dada, no le es permitida, como tampoco le fue permitida en la caverna platónica.

Si bien se acepta que el hombre, desde los tiempos modernos, ha avanzado significativamente en el plano de la ciencia y la tecnología, todavía está en sombras; peor aún: ha vuelto a ellas.

Para Molinuevo, la conjugación entre la creación y el mundo de las sombras platónico es la repuesta de nuestra cultura occidental al dilema entre el original y la copia.

Dilemas de este tipo solo tienen un trasfondo teológico y metafísico; la creación provoca el resurgimiento de la imagen de Dios como ser supremo ante una sociedad cristiana. La caverna, por su parte, obliga al hombre a reconocer el mundo de engaños y su condición de ignorante en la que ha estado desde siempre. La búsqueda de la verdad lo ha enceguecido, a tal punto que:

A la hora de examinar la dimensión cognoscitiva de las imágenes hay que tener en cuenta que, desde el punto de vista del pensamiento y del arte, la crisis del concepto de verdad como adecuación (de la mente a las cosas, de las cosas a la mente) tiene su paralelo en el de la imagen como representación. Ambos tienen en común conceptos subyacentes como son los de copia y exactitud. Todo esto se pone en cuestión en las nuevas tecnologías. No hay una teoría general de la imagen, ni menos todavía una idea general de la imagen, sino que estamos entre una variada tipología de estas que no reside únicamente en la diversidad de medios por los que son producidas (Molinuevo, 2004: 31).

De este modo, las tecnologías en la actualidad posibilitan la superación del dilema entre el original y la copia: solo que ya no es Dios el ser superior, el supremo, sino el hombre. Al buen estilo de Nietzche, el hombre de hoy, con las nuevas tecnologías y el desarrollo científico, juega a ser Dios, a tal medida que el superhombre es el resultado de la confluencia de «las nuevas tecnologías con el humanismo» (Molinuevo, 2004: 24). El ser humano, en su juego a ser Dios mediante el uso de la tecnología, altera todo orden, todo estado de cosas, trastoca todos los cánones de belleza, descarta ideales, ya no sueña, solo vive el momento. Se ha vuelto, masa, cosa, ente. La aridez del ser humano de hoy ha encontrado su oasis en la tecnología. Hoy,

[...] ese desierto del Ser como desierto de la vida es el contexto de la interacción en los años cincuenta y sesenta del siglo xx entre arte, naturaleza y tecnología. Porque la visión de esta última no corresponde ya ( 0 únicamente) a un producto de la razón, sino que se trata de una tecnoorgánica. Y en ella la técnica y las tecnologías son producto de lo elemental, del instinto, y se traduce en la particular relación erótica, carnal, que hay con las tecnologías, y que explicará [...] las sucesivas transformaciones del cuerpo y de la carne en el imaginario contemporáneo del video y del cine (Molinuevo, 2004: 28).

Las imágenes de hoy como reproducción del original -el asunto de la copia- son producto de la conjugación de la tecnología informática (hardware y software) y electrónica, más lo imaginado por el hombre. A partir del acelerado desarrollo de las tecnologías informática, ofimática, telemática y robótica, el hombre de hoy tiene la posibilidad de recrear su realidad, de hacer real lo irreal a partir del mundo de la realidad virtual. La digitalización de la realidad humana le posibilita al hombre recrear su propia morbosidad: el sufrimiento, la guerra, la muerte, el sexo, la religión, la política, el odio, el amor. Para Molinuevo:

El carácter autorreferente de las imágenes digitales introduce elementos hasta ahora desconocidos. Así sea en su versión idealista 0 realista, un modelo de pensamiento y de arte que había tenido en cuenta la ciencia se encuentra transformado por esta hasta el punto de dar un salto cualitativo (Molinuevo, 2004: 31).

La digitalización de las imágenes, la realidad virtual, le posibilitan al hombre alcanzar sus ideales, hacer posible 
sus fantasías, recrear su ideal de hombre, mujer, Estado, familia, sociedad; 0 , simplemente, recrear: crear y recrear una y otra vez los hechos de su acontecer diario. Es una realidad virtual sin humanos, porque el ser humano es imperfecto, inacabado, no es un ser absoluto. La realidad virtual reproduce, recrea, reformula una copia, una copia que por demás no es real, en tanto se establece a partir del ideal humano y no de la condición humana. Subyace así que:

Este posible mundo de imágenes sin sujeto es el que, en el fondo, asusta por su pretendido carácter deshumanizador. Algunos ya lo ven en el presente, en esa misma mutación y vaciado del ser humano a través de las sobredosis de información y de imágenes (Molinuevo, 2004: 31).

El mismo ser humano ha hecho posible la deshumanización de sí mismo, la pérdida de referentes comunes, reales: materiales, metafísicos, ontológicos, religiosos, políticos. En la actualidad, vemos cómo las tecnologías han generado en el hombre un alto nivel de dependencia hacia ella, donde la espontaneidad, las pasiones, las emociones, entran al mundo de la sospecha. Desde lo planteado por Molinuevo, sorprende comprobar cómo:

[... para el sujeto moderno, toda apariencia espontánea es sospechosa y negativa, ya que solo cree en aquello que proyecta y domina. Pero ese mundo, ese objeto que solo existe como reflejo, espejo del sujeto, deja a este en una profunda soledad. El yo moderno de la filosofía es un sujeto solitario. Paranoia y soledad son dos temas modernos y de la crisis de la modernidad (Molinuevo, 2004: 79).

Agrego por lo tanto del sujeto, con el agravante de que el hombre, la humanidad, ya no se piensan a sí mismos, ni siquiera como objetos.

Lo expuesto hasta ahora abre el planteamiento de que la realidad ya no es real: es inventada, programada, establecida, determinada, homogenizada, estandarizada. En el afán de la estandarización de los procesos, nos olvidamos de que el ser humano es un ser en la diferencia y desde ella. El avance tecnológico y científico de hoy abre el camino a la reproducción a partir del original: sacar copias, clonar el sujeto, pero no su ser y menos su esencia. La digitalización de la imagen posibilita mostrar, recrear, manipular el aparecer de la imagen humana, fenomenológicamente y ante las nuevas tecnologías. Su aparecer es la mínima representación de la copia. Lo cual no es más que:

[...] la descripción de la inautenticidad de la condición humana, de la necesidad de llevar una existencia auténtica, provocando un cambio en la relación con la verdad y, finalmente, del destino sacrificial del filósofo que cambia y quiere cambiar el estado de cosas (Molinuevo, 2004: 47).

En esta línea de cosas, le corresponde al filósofo, según Molinuevo (2004), identificar las condiciones y modos de aparecer del ser humano. La virtualidad no es la realidad: en el mejor de los casos, es una aproximación, incluso, en principio, desde la apariencia. La virtualidad se presenta como la condición real ideal, pero no como la realidad en sí, como en verdad es y se le presenta, la vive, la disfruta y la padece el hombre.

La virtualidad se asemeja a los sueños, a las fantasías, los cuales tienen un referente común: una posibilidad de verdad.

En la representación de la imagen, mediada por la tecnología, no es posible la reducción eidética de la imagen original: el ser humano. De ser esto posible, estaríamos presenciando el inicio de la «pérdida del original» (Molinuevo, 2004: 34). Hoy en día, ante la digitalización de su imagen, al ser humano solo le queda el cuerpo, materia que se deteriora en tiempo y espacio, pero que es recreada, rejuvenecida, hecha posible gracias a la tecnología. Imágenas, figuras, escenarios futuros que nos hacen soñar, princesas ideales que nos convierten el presente en un ensueño, son el producto de una gran industria: la de los medios de comunicación y el entretenimiento. 
El hombre contemporáneo es imagen, movimiento, es luz, color; el cine y el video, en tanto que conjugan todos estos elementos, se convierten en la condición bumana por excelencia. Desde la Modernidad y la Ilustración, la intencionalidad humana está carcacterizada por su obrar autónomo, sin dependencia de otro, pero termina siendo: «La forma de asumir la propia condición de copia, cuya repetición configura una identidad múltiple y efímera. Pocas veces este pensamiento en imágenes ha encontrado una expresión pictórica más adecuada» (34).

El cine, como representación, tiene el potencial de contar, mostrar, decir lo que el ser humano ha perdido: su capacidad de ver, contar y aceptar su cotidianidad, el trasegar del día a día. Además del cine, los cómics, el teatro, las telenovelas, las comedias, son un representar desde la intencionalidad de los mass media, que enmascara, tergiversa y acomoda la realidad del día a día.

[...] por eso quizá en la máxima obra de arte, en el cuerpo, donde el tema de la reproducción técnica sigue manteniendo hoy una vigilancia hermenéutica a través de fenómenos como la clonación, del sueño humano de descargarse en un cuerpo digital, etc. Y de esta forma «el cuerpo se vuelve digital, un Xerox del original». El cordón umbilical, que permite trazar una continuidad entre los comienzos del siglo xx y el xxi es el descubrimiento de la imagen en movimiento, y ello a través de un medio privilegiado: el cine (Molinuevo, 2004: 37).

El cuerpo digital, el mundo virtual, viene desplazando y anulando, desde la década de 1980, al hombre de carne y hueso. Lo grave de todo esto, parafraseando a Heidegger y retomando el escenario de las metáforas aludidas -la condición humana representada y el cambio de cultura acontecido-, es que el ser humano de hoy, ante el desarrollo tecnológico y el impacto de la misma tecnología, no piensa, no se da la posibilidad de pensar su condición humana, de pensar su ser, no cultiva su esencia, y, en cambio, se preocupa por su aparecer: su apariencia. Más grave aún es que el ser humano hace caso omiso de los referentes simbólicos, de las alertas que en su trasegar diario le salen al paso, le hablan de la necesidad de un alto, un cambio en el cómo hace las cosas, el cómo y el porqué hace ciencia y desarrolla tecnología. Al parecer, el hombre no tiene oídos, ni ojos, ni logos para esto.

\section{¿Qué es lo humano en tiempos de penuria, de impotencia ante el desarrollo tecnológico?}

iAh, mundo convulsionado: producto del obrar humano! Los logros de la humanidad en el siglo xx le han servido al hombre para enmascarar las grandes atrocidades cometidas por él mismo. La pregunta hoy es: ¿cuál es la condición del hombre en los tiempos posmodernos, especialmente después de mediados del siglo xx, cuando el desarrollo científico y tecnológico hizo su aparición con un nuevo artefacto de destrucción masiva: la bomba atómica? Este hecho, sin embargo, no es más que la sumatoria de situaciones acontecidas en tiempos y modos anteriores.

Durante el siglo xx, y más aún, en su período histórico entreguerras, el proyecto de modernidad fracasó; en muchos de sus intentos de desarrollo tecnológico, el hombre forjó máquinas de control social y exterminio, y se abrió una brecha entre él como ser humano y su dimensión espiritual, un elemento poco importante en un mundo tan técnico, tecnológico o mediatizado, heredado del positivismo europeo.

La incertidumbre y la disociación existencial del ambiente pesimista de la posguerra o de los grandes cambios económicos y sociales, dejaron al hombre a la deriva e hicieron que aumentara el contraste entre la pobreza y la riqueza, así como el recrudecimiento de las mafias, los nepotismos y la corrupción, y que una de las respuestas haya sido la réplica de las guerras y la penetración cultural de unos países respecto otros, y la superficialidad en la actitud del ser humano, como una válvula de escape ante la realidad-consumismo, depresión, aislamiento de todos y de sí mismo, uso excesivo de gadgets y dispositivos electrónicos, deshumanización, sincretismos religiosos, Nueva Era, etc.-. A pesar del panorama un tanto sombrío, 
todavía existen empresarios del espectáculo y artistas soñadores que piensan en un mundo para humanos, lo recrean y posibilitan espacios para vivir la realidad desde la realidad misma, no desde la fantasía y menos desde la ficción.

Hoy en día, en el arte, hay espacios que muestran cierta resistencia contra los estereotipos sociales; también, hay movimientos de rechazo en contra de los modelos idealizados de comportamiento manipulados por los medios masivos de comunicación, o que denuncian los excesos de la guerra.

El siglo xx hereda del siglo xix su legado; el siglo xix, a su vez, lo hereda de los siglos xv, xvi, xvii y xviii. Cada siglo guarda su pecado. En términos positivistas, existe un fino entramado de relaciones de causalidad entre estos períodos.

El siglo xix hereda muchos elementos de hitos acontecidos en siglos anteriores, en especial de aquellos que son fundamentales cuando al hablar de revolución científica se trata:

descubrimiento y conquista de América, el Renacimiento, la Ilustración, el Enciclopedismo, el desmonte de las teorías y los Estados absolutistas, el cambio de un modo de producción esclavista a uno feudalista, la Revolución francesa, la independencia de Estados Unidos de América. Teniendo como referentes estos elementos, es claro que al siglo xix no pueden atribuírsele todos los méritos de una revolución industrial: no es un asunto de mera coincidencia.

El siglo xix es un período para la historia de la ciencia y la tecnología en el que se alcanza un máximo de madurez y se da la posibilidad de desarrollo en las sociedades modernas. Por esto,

[...] los avances de la ciencia y el progreso tecnológico a ellos asociado parecían augurar un brillante porvenir.
Esta confianza en el futuro, esa fe en el Progreso, que descansaba en los logros alcanzados por la Razón, proporcionaba a las clases dirigentes del Viejo Continente la firme convicción de estar llamadas a desempeñar una misión histórica, ahora ratificada sobre bases científicas, de la superioridad de la raza blanca y de la civilización por ella engendrada, que servirá de cobertura ideológica a la expansión de los imperios europeos (Bahamonde Magro, 1992).

Esta es una tradición heredada, pero mal infundada. Las sociedades modernas han cambiado su dinámica de desarrollo y, por lo tanto, demandan más cantidad y novedad de servicios y productos. Los aires independentistas y la proclamación de los Derechos del Hombre proclamados por la Asamblea Nacional Constituyente francesa en 1789 y por Tomas Paine a mediados del siglo xix, determinaron un nuevo modelo de ciudadano, una manera diferente de concebir los modos de producción y la distribución de la riqueza. Es así como el hombre tiene nuevas experiencias de vida ligadas a factores de desarrollo industrial, técnico, tecnológico y científico; tal como lo plantea Alekséi Leóntiev en su texto El hombre, la cultura:

La experiencia social-histórica de la humanidad se concentra en forma de fenómenos exteriores del mundo objetivo que circundan al hombre. Este mundo, el mundo de la industria, la ciencia y el arte, expresa la verdadera historia de la naturaleza del hombre, el resultado de su formación histórica (Leóntiev, 1969: 21).

El hombre, a raíz del desarrollo científico y tecnológico, cuyo renacer se propicia en el siglo xix, es un sujeto ávido de desarrollo, ya no de simple conocimiento; ha acumulado toda una tradición de conocimiento científico, apenas un asomo de lo que será en el futuro -la segunda mitad del siglo $\mathrm{xx}-$, donde despliega toda su capacidad de conquista y destrucción:

[...] el hombre no nace dotado de las conquistas históricas de la humanidad. Las conquistas del desarrollo de las generaciones humanas no se hallan encarnadas en el hombre, ni en sus gérmenes innatos, sino en el mundo que lo circunda, en las grandes creaciones de la cultura humana (Leóntiev, 1969: 49). 
El hombre, aun con la negación de su ser, es historia, es cultura; sin estas dos variables no es posible hablar de evolución, progeso y desarrollo.

Los comienzos del siglo xix se caracterizaron por la «positivización de toda ciencia» y la inclusión de la historia como un componente válido en la comprensión de los hechos acontecidos en dicho siglo; estos dos aspectos hacen de las suyas a través de esos cien años, y posibilitan la confrontación y reformulación de los distintos modos de pensamiento y hacer ciencia en el siglo siguiente. No obstante, no es lícito desconocer lo representativo del siglo xix en materia de desarrollo científico y tecnológico en los distintos campos del desarrollo humano, pues allanó el camino para una mayor calidad de vida y mejores condiciones de bienestar social que disfrutó la humanidad en el siglo xx. La ciencia y la industria del siglo xix son el referente, ya hoy lejano, de lo que es el desarrollo científico y tecnológico de finales del siglo xx, el cual toma nuevos aires en la primera década del siglo xxi.

La desolación ha tocado al hombre en su ser. El mundo le queda pequeño, el mundo mismo es el hombre, y sus límites son su lenguaje: la capacidad del lenguaje en el hombre determina su mundo. En el siglo xx y lo que va del xxi, las nuevas tecnologías le venden la idea de tener el don de la ubicuidad, le posibilitan la simultaneidad en el aparecer; pero el hombre, en su esencia, ya no es el «protagonista de la película»: el hombre de hoy, en la cultura de la imagen, de los efectos, es un instrumento de entretenimiento más; la industria lo toma como material de desecho, sea para producir o consumir. El ser humano actual ha dejado sus necesidades y condiciones naturales para dedicarse a las artificiales. Valga esta verdad de Molinuevo:

El hombre ya no es el centro del universo, sino una flecha en el arco tenso de la propia vida que apunta en un misticismo cósmico a desconocidos Puntos Omega, tal como refleja en sus grabados Masson. ${ }^{2}$ Pero el problema de la religión de las nuevas tecnologías es que nunca falla, y el hombre debe saber bien lo que quiere y lo que pide, como adelantaba Norbert Wiener, ${ }^{3}$ no sea que se cumplan sus deseos. El futuro nos presenta un hombre que sigue siendo un misterio para sí mismo y una Tierra que es una gran desconocida (Molinuevo, 2004: 68).

Entonces, ¿dónde queda lo humano?, ¿qué es lo humano hoy? Realizo una reflexión, como posible respuesta, a partir de Ortega y Gasset, en especial desde la relación que hace del ser humano con la técnica en el siglo xx. El hombre, a finales del siglo xix, pidió, se proyectó tímidamente, y se le dio de más. En el siglo xx, frotó la lámpara de la tecnociencia, y los deseos cumplidos colmaron en número, condiciones y calidad sus expectativas de vida y desarrollo; ahora no sabe qué hacer con las condiciones y modos de desarrollo que le posibilitan la ciencia y la tecnología. El hombre del siglo xx, y el de los albores del xxi, se atrofia con el exceso de comodidades, muere lentamente en el uso excesivo de la tecnología. Vivir en la riqueza, la opulencia, la gula, no es «vivir» en el ser humano; la casa del ser no es habitada por la mezquindad y la avaricia. Ortega y Gasset lo plantea de la siguiente manera:

El hombre no quiere morir; al contrario, normalmente
anhela pervivir. Estamos tan habituados a experimentar
en los demás y en nosotros este deseo de vivir, de
afirmarnos frente a toda circunstancia negativa, que nos
cuesta un poco caer en la cuenta de lo extraño que es, y
nos parece absurda o tal vez ingenua la pregunta: ipor
qué el hombre prefiere vivir a dejar ser? Y sin embrago, se
trata de una de las preguntas más justificadas y discretas
que podamos hacernos (Ortega y Gasset, 2002: 22).

El hombre actual carece de autencticidad, su ser se ha desvanecido. Lo vaticinaba Ortega y Gasset a comienzos del siglo xx. Al hombre de ese tiempo, presente hoy, le interesa ser y hacer parte de la producción en masa, de los procesos robotizados y automatizados, incluso en aquellas acciones que lo dignifican como especie humana: pensar, soñar, sentir, padecer, amar, llorar, reír, hacer el amor.

Según Ortega y Gasset, los instintos en el hombre están casi extintos; parece ser que las condiciones de sentir, padecer 
y disfrutar le son vedadas. Hablar desde lo instintivo es equipararnos con los animales:

El animal no puede retirarse de su repertorio de actos animales, de la naturaleza, porque no es sino ella, y no tendría, al distanciarse de ella, dónde meterse. Pero el hombre, por lo visto, no es su circunstancia, sino que está solo sumergido en ella y puede en algunos momentos salirse de ella y meterse en sí, recogerse, ensimismarse y solo consigo, ocuparse en cosas que no son directa e inmediatamente atender a los imperativos o necesidades de su circunstancia (Ortega y Gasset, 2002: 27).

Aquí, el autor nos ratifica la importancia del instinto en el hombre, porque, en teoría, y aunados a su capacidad reflexiva, su libre albedrío y su voluntad son los que le posibilitan salir de la masificación y cosificación en que lo han metido la ciencia y la tecnología de hoy. El hombre, al negarse a obrar según sus sus instintos, está negando su ser, su naturaleza humana. La dimensión espíritual, teleológica, le es negada o, en el mejor de los casos, le es cambiada.

Es así como el hombre se hace competente en la vision tecnocrática y productiva del mundo, pero inepto en el manejo adecuado de su dimensión espiritual y pone en juego su capacidad de razonar.

Piensa, calcula y evalúa antes de actuar, se comporta según una racionalidad matematizada; son la capacidad de reflexión y la voluntad las que obligan a que no dé rienda suelta a sus instintos. El obrar instintivamente es un obrar animal, natural en el hombre; son su primera condición y realidad natural, pero no se quedan allí: es el desocultamiento de la técnica, que hace presencia de modo natural.

[...] la vida humana, pues, trasciende de la realidad natural, no le es dada como lo es dado a la piedra caer y al animal el repertorio rígido de sus actos orgánicos -comer, huir, nidificar, etc.-, sino que se la hace él, y este hacérsela comienza por ser la invención de ella (Ortega y Gasset, 2002: 44).
Desde antes de existir, el hombre es un padecimiento constante, un ser desvalido, que requiere de los demás para las condiciones mínimas de vida: el abrigo, la alimentación, la movilidad. Por otro lado, ese padecer es lo que alienta su existir, lo que lleva a que: «[...] la existencia del hombre, su estar en el mundo, no sea un pasivo estar, sino que tenga, a la fuerza y constantemente, que luchar contra las dificultades que se oponen a que su ser se aloje en él» (Ortega y Gasset, 2002: 47).

Ahora bien, la angustia del hombre de hoy no es por su ser ni por el padecer de su ser. El padecer, como judío errante, es por la pérdida del tiempo y el espacio. El mundo virtual, como producto del desarrollo científico-tecnológico, ha desmontado las variables de tiempo, modo y espacio. Como lo plantea Ortega y Gasset, ante la tecnología, el hombre es:

[... algo que no tiene realidad ni corporal ni espiritual: es un programa como tal; por lo tanto, lo que aún no es sino que aspira a ser. Se dirá que no puede haber programa si alguien no lo piensa, si no hay, por lo tanto, idea, mente, alma o como se le quiera llamar (Ortega y Gasset, 2002: 48).

El hombre está constante y complejamente teledirigido; somos culturas televisuales que devienen de una identidad híbrida o de una no-identidad: el X-Box, el Wii y los demás juegos de video, los ordenadores, el automóvil con su gps, los Ipods, todos estos artefactos lo sustraen de un principio de realidad integrador que le haga interactuar con el otro, o tener un coloquio con él. Los códigos lingüísticos y el sistema-mundo de hombre de hoy se le cambian... y ni siquiera lo percibe.

El hombre de hoy es un ser desnaturalizado: el ser de la naturaleza y el ser humano no coinciden, no compaginan. El ser humano ante la naturaleza es un híbrido; por un parte, responde a las condiciones que ella misma le ha otorgado, pero, en ocasiones la supera. Es así como «media porción de él está inmersa, desde luego, en la naturaleza, pero la otra parte trasciende de ella» (Ortega y Gasset, 
2002: 47). En su afán de trascender, de inmortalizarse, el hombre se anula, pierde su condición de sujeto y asume la de cosa, ni siquiera la de objeto. Se puede, por lo tanto, definir también que «el hombre no es una cosa, sino una pretensión, la pretensión de ser esto o lo otro. Cada época, cada pueblo, cada individuo, modula de diverso modo la pretensión general humana» (49).

La época del ser humano de hoy es la de la tecnología, la deshumanización, no como regreso a su condición primitiva, de mero primate superior, Homo sapiens: la deshumanización de hoy es el resultado de su irracionalidad. Sorprende comprobar que «La naturaleza ya no acoge en su seno al hombre, sino que es un torbellino desquiciado que grita, y de cuyo grito insoportable se hace eco el hombre tapándose los oídos. Pero esa catástrofe es la que él mismo ha propiciado» (Molinuevo, 2004: 83).

La irracionalidad del hombre es principio y el fin de su máximo esplendor, pero también muestra el ocaso de su existir -su extinción- para llegar a concebirse como sermáquina. La hibridación apenas comienza, acaece, no obstante que en las sociedades tecnologizadas de hoy:

Los seres humanos son solo marginalmente racionales y, por otra parte, con su aceptación de la muerte se niega la posibilidad de una inmortalidad que está al alcance de la mano con las nuevas tecnologías. Se trataría de cambiar de dirección y de buscar el origen de lo extraordinario en lo ordinario, sin hacer caso de la religión y el misticismo, que quieren hacernos creer que debemos estar agradecidos por la existencia a un supremo ser (Ortega y Gasset, 2002: 83).

\section{El ser humano en los contextos contemporáneos: el humanismo tecnológico como un asunto de riesgo para el hombre}

El devenir científico y tecnológico de finales del siglo xx e inicios del xxi toma nuevos aires, mas no en términos de rejuvenecimiento: a la postre, el objetivo sigue siendo el mismo: conquistar el mundo, a costa de lo que sea y por encima de quien sea. El mundo de las imágenes hoy en día es mediado por la tecnología, pero la manipualción de la imagen real, su digitalización, distorsiona el original. Ya no es el objeto o situación allí presente para todos: no. Solo aceptamos lo que el otro, desde su visión e intencionalidad sobre las cosas, nos quiere presentar. Ya no es la imaginación como condición del ser humano hoy, sino la imaginería de un sujeto que digitaliza la imagen y la recrea, le da identidad. Al respecto, Ulrich Beck en su texto «Retorno a la teoría de la sociedad del riesgo» anota:

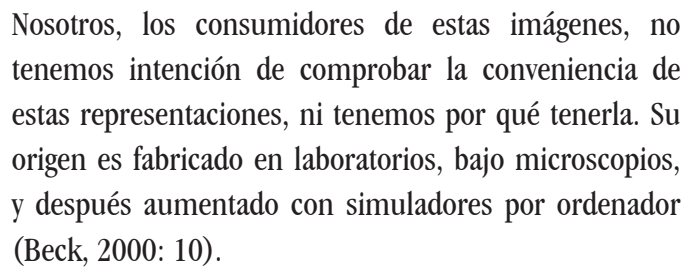

La imagen se manipula, y la ciencia especula con el fenómeno haciendo uso de la tecnología.

La ciencia altera el fenómeno en doble sentido: por un lado, lo explora e interpreta de manera inductiva y deductiva, hasta su más mínima expresión; por el otro, aumenta el fenómeno mediante condiciones simuladas, alterándolo de una realidad en sí, en especial con su aparecer, para generar miedo a la sociedad. La ciencia manipula, transforma la imagen real-original, para hacerse ver como la panacea, la salvadora de los desastres que se ha causado el hombre a sí mismo. Estableciendo la intencionalidad de la tecnociencia, sobran razones para decir que:

Los riesgos en los que se cree son el látigo empleado para matener el momento presente corriendo a galope. Cuanto más amenazantes sean las sombras que caen sobre el momento presente desde el terrible futuro que asoma en la distancia, más inevitable la conmoción que puede provocarse hoy por la dramatización del riesgo (Beck, 2000: 12).

El ser humano de hoy -y de siempre- no comprueba, no mide el impacto, no visualiza el riesgo de su desarrollo. La ciencia, entonces, ante ese enceguecimiento, amplía la imagen, proyecta un escenario futuro; sin embargo: 
La deshumanización se refiere, más bien, a cómo el hombre está, no a cómo es o debe ser. Y se concreta en que es deshumanizadora la situación en la que el ser humano, al estar oprimido sufriendo la injusticia, no puede ejercer sus derechos y obligaciones como individuo (Molinuevo, 2004: 176).

Desde la intencionalidad de este texto, es obligado pensar en la pérdida del ser humano: ya no es el ser humano en sí: simplemente es otra cosa, otro fenómeno: es un híbrido que reclama nombre, identidad, presencia, protagonismo.

La ciencia y la tecnología -la tecnociencia- nos hacen ver el riesgo de los hechos acontecidos, pero no en el presente, sino en el futuro. Hoy en día, y desde mediados del siglo xx, ha comenzado el tiempo y el modo de la sociedad del riesgo. Pero lo pasado es pasado; el futuro es el riesgo. Lo hecho en el pasado y manifestado en el presente son el desastre, el acabose de lo humano, productos de la irracionalidad y la ambición humanas. Como lo plantea Beck:

Los riesgos no aluden a daños acontecidos. No equivalen a destrucción. Si fueran lo mismo, todas la compañias aseguradoras habrían ido a la quiebra. No obstante, los riesgos amenazan con la destrucción. El discurso del riesgo empieza donde la confianza en nuestra seguridad termina, y deja de ser relevante cuando ocurre la potencial catástrofe. El concepto de riesgo delimita, por tanto, un peculiar estado intermedio entre seguridad y destrucción, donde la percepción de riesgos amenazantes determina pensamiento y acción (Beck, 2000: 10).

Hoy, el riesgo desde lo humano es la inacción. El riesgo para el hombre de hoy comprende todo. A la luz de lo desarrollado en el presente texto sobre las metáforas y lo relatos, como lo anota Molinuevo:

Lo que dicen esos grandes relatos es que el futuro es híbrido. La conjunción entre humanismo y nuevas tecnologías en el presente proyecta en el futuro el humanismo híbrido de una cultura de collage. Los grandes relatos tienen por objeto, no la figura de la estatuaria clásica del héroe, sino la astucia de la metamorfosis, no la sustancia estática, sino el cambio de la identidad proteica. El futuro ya no es una meta sino una transición hacia otros presentes sin fin (Molinuevo, 2000: 94).
El riesgo como futuro es incierto; de este modo, los riesgos no pueden ni deben ser vistos, comprendidos y asumidos fuera de contexto. Si bien el concepto de ser humano es uno, y en esta medida es válido para todos, en cualquier cultura y sociedad, de manera universal, el riesgo se visualiza en la particularidad. La dualidad global/local se asume en la valoración del riesgo, pero no en su origen como posibilidad, pues el riesgo también es incertidumbre.

Cuando la sociedad del riesgo posibilita la valoración científica y tecnológica del riesgo mismo, nos lleva a admitir que el hombre deshumnaizado de hoy, sea por su radical irracionalidad o por el exceso de sus pasiones, no es «[...] nada más que máquinas: pobre costumbre engañosa, creemos que nosotros mismos somos criaturas intencionales, responsables, mientras que en realidad no somos nada de eso» (Molinuevo, 2004: 99). Se tiene, en consecuencia, que el humanismo tecnológico es un híbrido en los tiempos de la posmodernidad, no siendo esta algo más que una prolongación del ideal de la modernidad: el humanismo. Es así como se habla hoy de un humanismo tecnológico, el cual, según Molinuevo:

Surge del cruce de modernidad con la vida corriente. Se trata, no de un humanismo basado en la humanidad (tesis idealista), sino en el individuo. El individuo no es el sujeto. No tiene sentido hablar en sentido reduccionista de un humanismo del sujeto para así criticarlo mejor, como ha hecho Heidgger. Con el humanismo del individuo se trata de potenciar la otra gran categoría moderna, la de relación, no la de sustancia o subsistencia. Esta es la base de las nuevas tecnologías de la información y comunicación (Molinuevo, 2004: 178).

En otras palabras, es el resultado de la pérdida de los ideales de libertad, voluntad y autonomía, concebidos en la modernidad y el desarrollo científico y tecnológico del siglo xix. En la modernidad es reconsiderada la importancia del humanismo, heredado a su vez del Renacimiento. No es casual, entonces, que en tiempos posmodernos como el nuestro, no sean las tecnologías y su permeabilidad en términos de hibridación «[...] las causantes de la 
deshumanización, sino individuos deshumanizados. La deshumanización social, económica, cultural es la causa de la deshumanización tecnológica y no al revés» (Molinuevo, 2004: 168). Paralelo con lo establecido, la idea es que se pueda evidenciar «Un humanismo tecnológico tiene como premisa, no el ideal de la dignidad del ser humano, sino el presente de su dignidad, del sufrimiento que causan o toleran unos seres humanos a otros, injusta e innecesariamente» (175).

El hombre posmoderno es un padecer constante. El humanismo tecnológico lo ha desplazado, lo ha desalojado de la casa de su ser. El ser humano es víctima de su propio desarrollo, de su evolucionar impensado y, en ocasiones, de su ceguera irracional. En conclusión, su puede demostrar que:

Las tecnologías tienen un origen humano. Pero, siendo instrumentos de dominio, esto no implica que el hombre controle todo con ellas ni que las controle. Tampoco que sus acciones tengan las consecuencias adecuadas a sus propósitos. La teoría de la inintecionalidad de las acciones humanas es hoy una teoría tan humanista como la de la intencionalidad de estas. No es la amenaza de la técnica, ni el deseo de humanizarla, frente a una posible deshumanización, lo que impulsa el humanismo tecnológico. La técnica y la tecnología hace tiempo que se le han escapado al hombre, como tantas cosas, y no son una excepción. Tampoco un drama. Lo que impulsa la propuesta de ese humanismo tecnológico no es un afán idealista ni redentor (nadie debe salvarnos de lo que somos), sino posibilista, desde los límites humanos. Si las tecnologías han ganado en poder y velocidad antes inimaginables, quizá puedan ser algunas encauzadas en provecho de los seres humanos; el discurso sobre las nuevas tecnologías hoy, más que una descripción de su variedad, es un análisis de cómo está en ellas y con ellas el hombre tecnológico. Antes se cuestionaba qué hacer con ellas; ahora debe también preguntarse qué están haciendo y han hecho con nosotros. Ahora las tecnologías han ocupado para algunos el lugar de los coléricos dioses de Sísifo. Volver a reproducir lamentos deterministas no tiene sentido (Molinuevo, 2004: 177).

Llegado a este punto, no resta entonces sino plantear que en los tiempos actuales no se pregona $-\mathrm{y}$ menos a mi juicio- un rechazo u odio a la tecnología y al desarrollo de la ciencia. No es ese el caso. Lo que sí queda claro es que el hombre de hoy se ha dejado absorver por sistemas y modos de vida artificiales, que no solo lo distancian de su condición como humano, al menos como hasta el día de hoy se ha concebido, sino que, por el afán de asumir esos modelos, la humanidad misma se ha olvidado de vivir, de sentir, de compartir, de reír y de disfrutar de lo más simple.

Al hombre de hoy se le ha olvidado que la felicidad está en lo simple, no en lo complejo; que su ser deviene de lo natural y no de lo artificial.

Adicionalmente, es evidente que a los medios de comunicación en general y a los sistemas de producción industrial y económica en particular no les interesan la deshumanización del hombre mientras este siga siendo un objeto de producción y consumo, una cosa más dentro del sistema, que en cualquier momento puede ser remplazado, moldeado según las situaciones de preferencia y necesidades del sistema. Al hombre de hoy no solo se le lleva a pensarse y verse como objeto, cosa, masa, sino, y más grave aún, es que sabe que el mundo de hoy, en las condiciones como está planteado, es una mascarada, que su felicidad se presenta como una utopía, y que debemos darle gracias a Dios y al sistema por ser tan bueno con nosotros $(\ldots)$.

Todo esto, en resumidas cuentas, no es más que un llamado de atención sobre el desarrollo de la ciencia y la tecnología y su impacto en la sociedad; y hablo de sociedad, porque la individualidad, como un ideal de la modernidad y de la Ilustración en el contexto del humanismo tecnológico, es una variable de su desolación, del impacto negativo que ha tenido el mismo desarrollo, en la medida que no solo ha perdido su bumanidad, sino que ha puesto en riesgo los niveles de sustentabilidad y sostenibilidad del medio ambiente y las demás especies vivas del planeta. Se ha dado el lujo de decir: para qué planeta, para qué mundo sin bumanos. 


\section{Bibliografía}

Agazzi, Evandro (1996). El bien, el mal y la ciencia. Madrid. Tecnos.

Aguilar de La Rosa, Gladys (2006). «Reflexiones en torno al transcurso de la ciencia y la tecnología en el desarrollo de la humanidad». S. 1. Perfiles. Enero-abril. S. p.

Bahamonde Magro, Ángel, coord. (1992). «Ciencia y pensamiento en Europa: apogeo y crisis de la razón moderna, 1848-1927». En: La época del imperialismo. Vol. 11, en: J. Fontana, dir. La Historia Universal Planeta. Barcelona. Planeta. Sitio web: Luis Enrique Lotero Carvajal. Disponible en: http:// www.ucm.es/info/hcontemp/leoc/ciencia\%20en\%20 europa.htm Consulta: 17 de agosto de 2009.

Beck, Ulrich (2000). «Retorno a la teoría de la sociedad del riesgo». S. 1. Boletín de la a. g. e. Núm. 30, pp. 9-20.

Chaves, P. Julián (2004). «Desarrollo tecnológico en la primera revolución industrial». Norba. Universidad de Madrid. Taurus. (2002). Ciencia y Técnica. Madrid. Siglo XXI.

Koyré, Alexánder (2000). Estudio del pensamiento científico. México, D. F. Siglo XXI. Pág. 394.

Leóntiev, Alekséi (1969). El hombre de la cultura. México, D. F. Grijalbo.

Medina, Manuel y José Sanmartín, eds. (1990). Ciencia, Tecnología y Sociedad. Barcelona. Antropos. Pág. 222.

Molinuevo, José Luis (2004). Humanismo y nuevas tecnologías. Madrid. Alianza.

Ortega y Gasset, José (2002). Meditaciones de la técnica y otros ensayos sobre ciencia y filosofía. Madrid. Alianza-Revista de Occidente. 
त R E V I \& T A EENCIA TECNOLOGÍA SOCIEDAD 


\section{Adriana Ocampo}

Homenaje a la primera colombiana

en ingresar a la Administración Nacional del Espacio (NASA). Primera colombiana en trabajar con la NASA en las Misiones Vikingo (Consistían en determinar si en Marte existía vida). Geóloga y científica en el campo aeroespacial, en su trabajo para optar al título de Magíster fue la primera en demostrar que el cráter de chicxulub estaba relacionado con la extinción masiva ocurrida hace 65 millones de años.

Título: Marte

Técnica: Grafito sobre papel Autor: Frank Vélez Penagos

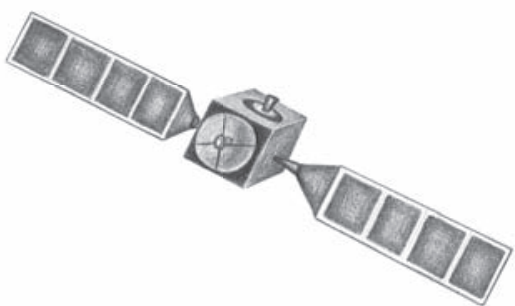
Año: 2011

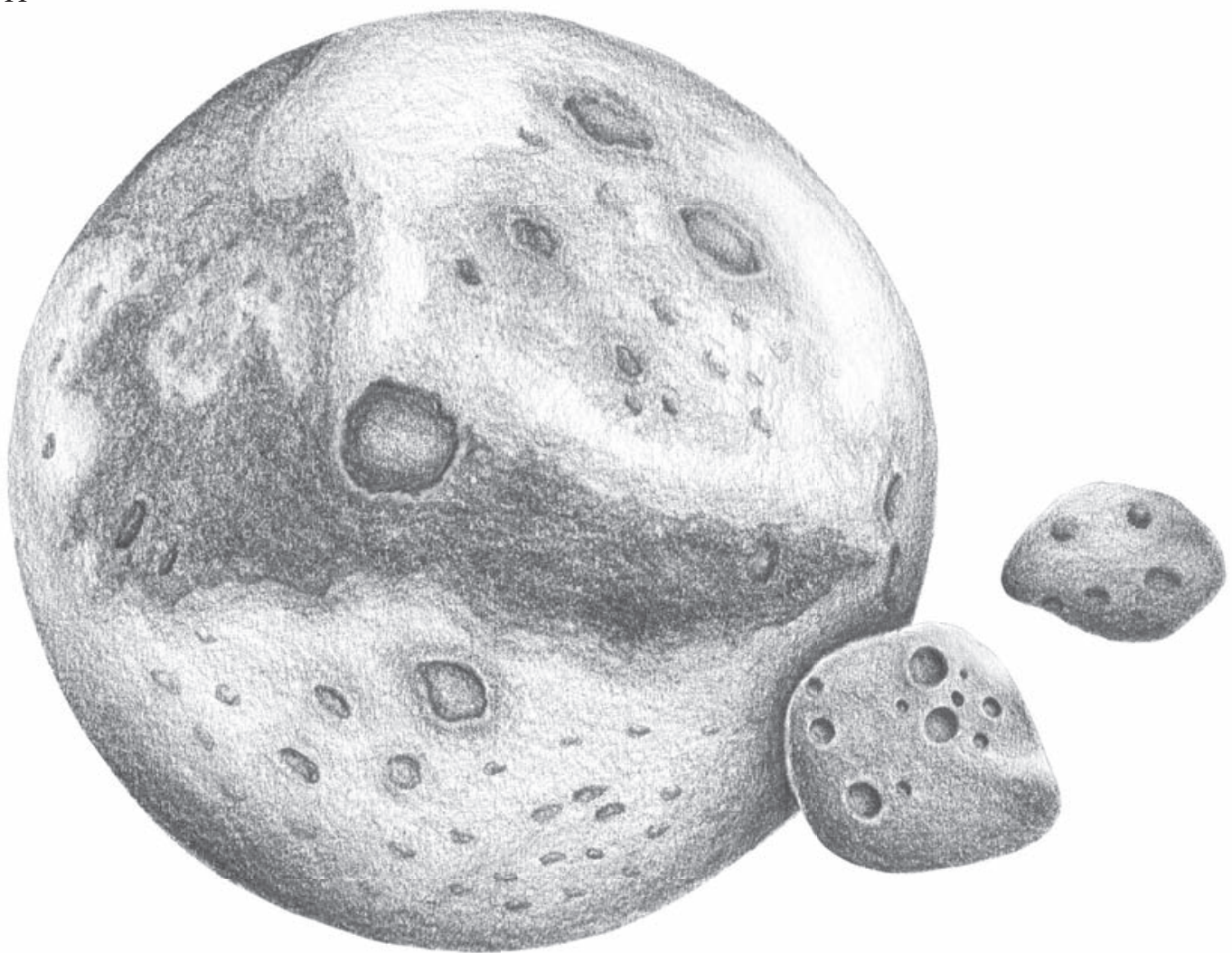


$\approx \mathrm{R}$ E $\mathrm{V} / \mathrm{I} \boldsymbol{\mathrm { T }} \mathrm{A}$ EENCIA TECNOLOGÍA SOCIEDAD
Número $4 \bullet$ abril $\bullet 2011$

80

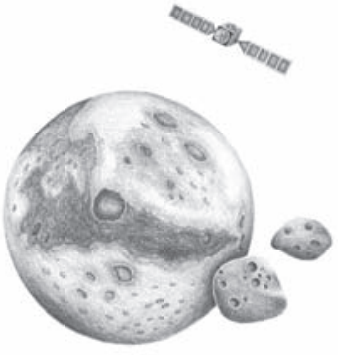

